\title{
Democracy at Risk: How the Electoral College Undermines Political Equality and Effective Governance
}

\author{
Chong Zhang ${ }^{1}$ \\ ${ }^{1}$ The Chinese University of Hong Kong, Hong Kong SAR, China \\ Correspondence: Chong Zhang, The Chinese University of Hong Kong, Shatin, NT, Hong Kong SAR, China. \\ E-mail: 1155165894@link.cuhk.edu.hk
}

Received: January 10, 2022

doi:10.20849/ajsss.v7i2.1003
Accepted: February 10, $2022 \quad$ Online Published: February 27, 2022

URL: https://doi.org/10.20849/ajsss.v7i2.1003

\begin{abstract}
This study aims to illustrate the political inequality and the lack of representativeness of the U.S. presidential election system by analyzing the flaws of the Electoral College system. Increasingly influenced by political polarization, money, and social media, nowadays the U.S. presidential election has become more susceptible to being manipulated so the winner's governance ability cannot be guaranteed. The U.S. presidential electoral system needs to be reformed to better reflect the will of the people, ensure democratic legitimacy, and achieve effective governance.
\end{abstract}

Keywords: the Electoral College, the United States, presidential election, democracy, national governance

When the founding fathers met in Philadelphia in 1787 to determine how to choose a President, an important consideration is enough separation of legislative and executive powers, guaranteeing the independence of the President (Kurdova, 1994). In addition, the direct election was an unrealistic method at that time because of the lack of resources and transportation, and constitution-makers were skeptical of common citizens' ability and awareness of participating in politics. In other words, instead of being chosen, the Electoral College was accepted as a compromise out of the fear of a powerful monarch (Kurdova, 1994) and the impracticability of direct election. So at the beginning of the establishment of the Electoral College, it deviated more or less from the principle of democracy. Nowadays with the intense political polarization, the corrosive influence of money in politics, and the development of information technology, this electoral system is already a product of a bygone age (Gaughan, 2016), which damages not only people's confidence in democracy but also the national governance.

\section{Winner-Take-All: An Electoral System With Flaws}

The constitution of 1787 gave the power to determine the electoral method of individual electors to each state. Initially, there were mainly three methods of choosing electors: appointment by the state legislature (Moore, Preimesberger, \& Tarr, 2001), district mode (Ross, 2015), and universal suffrage based on winners-take-all system, and the latter has become a universal practice (Godek, 2018).

The abandon of district mode ran counter to the original intention of constitution-makers who believed that the electors should be "selected by their fellow-citizens from the general mass" district by district and are "most likely to possess the information and discernment requisite to make decisions regarding the selection of a president" (Hamilton, 1788). While the popularization of the winner-take-all method leaves the control of the selection of the President in the hands of 538 electors who form the Electoral College rather than all American citizens (Gaughan, 2016), violating the democratic principle of "one person, one vote". Nowadays the winner-take-all system is used in 48 states (Main and Nebraska are the only two states to adopt a combination of district method and universal suffrage). If a candidate wins the popular vote in that state, he or she will get all electoral votes for that state, even if that win is $50.1 \%$ to $49.9 \%$ (Marlowe, 2020). Besides, a candidate will win the electoral votes in the state as long as he or she wins a plurality instead of a true majority of votes, even the percentage of vote is under 50\% (Golder, 2006). So this system also violates the democratic principle of majority rule. In this way, if the plurality of electoral votes for the state is $30 \%$, then anyone who has not voted in that $30 \%$ will not be represented by the electors (Marlowe, 2020). There have been five elections in which the winner of the Electoral College was not the winner of the popular vote: John Quincy Adams in 1824; Rutherford B. Hayes in 1876; Benjamin Harrison in 1888; George W. Bush in 2000; and Donald Trump in 2016. The repeated 
divergence between the popular vote and the electoral vote aggravated the unrepresentative of the citizen's wishes and proved the undemocratic nature of the system (Marlowe, 2020) because it makes some people's voices not matter at all.

\section{Big States Hold Small States Hostage}

Electoral votes are distributed among the 50 states based on the Census. Apart from the capital Washington, DC which is allocated three electors, each state has two fixed votes plus a number of votes allocated according to the size of its congressional delegation. Thus the number of people per electoral vote differs greatly from state to state. In 2008, a state is allocated one electoral vote for every 565,166 people on average. While Wyoming has three electoral votes and only has a population of 532,668 citizens. So each of the three electoral votes represents 177,556 people, which means that people in Wyoming enjoys 3.18 times as much clout in the Electoral College as an average American (FairVote, n.d.).

However, this is just one way of simply measuring a voter's clout in elections, states with larger populations already determine elections. Under the Electoral College system, all big states adopt the winner-take-all mode, thus they can maximize the advantage of having more electoral votes, putting small states at a disadvantage. For example, states like California and New York have more influence in the election than places like Delaware because they have more representatives to vote for a candidate. So presidential candidates will make more political promises to "flatter" voters in big states in order to win in the Electoral College, making some votes matter more than others.

\section{A Two-Party System}

The "single-member-district plurality" electoral system based only on a plurality of votes not a majority has led to the two-party system (Lipset \& Marks, 2000). In addition, compared with most Western European countries where a candidate still needs to be selected by the parliament after the elections, the presidential election in the U.S. has a different dynamic because there is less pressure for the two pre-electoral coalition parties (Domhoff, 2014). The two major parties form the largest possible pre-election coalition since the vote for a third-party or independent candidate is a vote for "their worst enemy" (Domhoff, 2014). According to Lijphart's patterns of democracy, increasing the diversity of political parties can improve the level of democracy in a country (Lijphart, 1999). But the "two-party system" in the U.S. has maintained the monopoly over electoral politics for more than 150 years since the Whigs were replaced by the GOP in the 1850s (Galen, 2018), making it difficult for a third-party or independent candidate to be placed on ballots and win elections (Parenti, 1995).

In the history of the U.S. election, no independent candidate has won a considerable number of votes except for George Washington, the first President of the United States. Almost all U.S. presidents have come from one of the two major parties-the Democratic Party and the Republican Party, except John Adams from the Federalist Party, Thomas Jefferson and James Madison from the Democratic-Republican Party. It is rare for a third party or independent candidate to get nominated let alone win the election.

The two-party system in favor of extremists has caused serious polarization among candidates. However, on most social issues, the majority of voters do not have a strong political leaning (Nivola \& Brady, 2007). According to Gallup polling of 2020, $41 \%$ of Americans identified as independent (Gallup, n.d.). A manifestation of the failure of the American democratic system to respond to the will of the people is that, although Democratic and Republican candidates from the same state represent the same voters, they pursue different and even opposing policies (Bartels, 2016).

\section{Ballot Access}

The two parties manipulate rules to set limitations and barriers to prevent political outsiders from participating in elections (Galen, 2018). To be placed on the general election ballot in all 50 states and Washington, D.C., an independent presidential candidate must submit a petition with a signature requirement (only a few states allow an independent candidate to pay a filing fee in place of a petition) (Ballotpedia, n.d.). Although the requirement for the number of signatures differs from state to state, sometimes an independent or minor party candidate must collect much more signatures than a partisan candidate to be listed on the ballot. For example, in Arizona, a Republican or a Democrat only need to collect about 6,000 signatures while the number is six times higher for an independent — around 37,000 valid signatures to appear on the ballot (Galen, 2018). To collect so many signatures, independent candidates need to raise a lot of funds by themselves because they are also excluded from the public funding which is designed to fund the major party nominees' general election campaigns (FEC, n.d.). The two parties' duopoly over electoral politics makes voters take third-party or independent candidates as fringe groups which are unlikely to win, thus their votes are doomed to be wasted (Galen, 2018). To a large 
extent, the original intention of independent and third-party candidates is to implement some policy ignored by the two major parties and speak for minority groups. However, the current system does not give equal opportunity for all citizens to be represented (Marlowe, 2020).

\section{Battleground States and Safe States}

The imparity between the battleground states (or swing states) and the non-battleground states is a political product of the two-party system and the winner-take-all system. The partisan leaning of those battleground states is unclear, so both Democratic and Republican parties have a chance to win the popular election in these states. Before the presidential campaign, they estimate the probability of winning in each state based on polls. Unless having an absolute advantage, they will try to get as many votes as possible in those swing states to ensure victory in the presidential election. Since there is no need to waste resources campaigning in safe states where they have an overwhelming advantage or an absolute disadvantage, so presidential candidates tend to only focus on several battleground states, such as Florida and Ohio (Polsby, Wildavsky, \& Hopkins, 2008) which often determine the election result, rending much of the country irrelevant in the general election (Gaughan, 2016). From 1988 to 2004, battleground states received on average 70\% of presidential campaign visits and advertising dollars (Gerber, et al, 2009). While safe states such as California, New York, Alabama, Michigan, Tennessee, and Illinois are conventionally ignored (Gaughan, 2016). In 2016,94\% of the general-election campaign events in the presidential race took place in 12 states (National Popular Vote), 11 states of them were identified as battleground states (Stanage, 2016; Shepard, 2016). As a former presidential candidate and Wisconsin Governor Scott Walker said, "The nation as a whole is not going to elect the next president, 12 states are" (LoBianco, 2015).

The biggest population difference between the battleground states and other states is the proportion of racial minorities: there are fewer Blacks, Latinos, Asians, and Native Americans in battleground states (Goux \& Hopkins, 2008). As a result, the voice of minority groups would be diluted. When a candidate promises policies in favor of citizens in a battleground state in order to win the election, those residents enjoy concrete benefits that are unavailable to their counterparts in non-battleground states (Bennett, 2006; Goux \& Hopkins, 2008). It is undemocratic to increase intentionally the importance of some people's vote while limiting the impact of others.

\section{Following the Money}

"The United States sports perhaps the most smoothly efficient money-driven electoral system in the world" (Ferguson, 1995). In the nineteenth century, bosses in big cities such as New York and Philadelphia loaded up their supporters with beer and arrange them to vote under aliases at different polling stations (Gumbel, 2008). Then in the age of robber barons when the vote of industrial classes jeopardized the expansion of capitalism, literacy tests and "good character" tests were introduced to set obstacles for voters (Gumbel, 2008), and many low-income voters were also disenfranchised (Kousser, 1974). In 2010, the Supreme Court ruled that the political spending by enterprises was a kind of free speech right and removed the restrictions on political spending by corporations in candidate elections. This is a major victory for powerful interest groups (Liptak, 2010) and the intervention of capital in politics has reached an unprecedented level. In the 2016 presidential election campaign, Hillary Clinton spent $\$ 1.4$ billion and Donald Trump $\$ 957.6$ million, both of them received donations from rich businesspeople whose donation was up to over $\$ 20$ million per person (Narayanswamy, Cameron, \& Gold, 2021). Other democratic countries have clear upper limits on election expenses. Take France as an example, a presidential candidate can spend a maximum of 16.8 million euros during the first round of the election campaign and about 22 million euros in the second round; individual donations cannot exceed 7,500 euros a year to a party and a maximum of 4,600 euros to a presidential campaign; corporate firms are prohibited from financing the candidates (Willsher, 2007).

\section{The Exorbitant Entrance Fee}

The U.S. is a country that thrives on fierce competition and there are few areas where competitions are more cutthroat than elections (Gumbel, 2008). To successfully "market" themselves in elections, presidential candidates must ensure that they are known to the public. So resorting to expensive media campaigns becomes a necessity. As the public funds provided by the federal government cannot satisfy the vaulting ambitions of candidates, they have to rely on economic elites to fund their campaign activities. In the 2016 presidential campaign, Hillary Clinton raised the highest amount of money ever for a Democratic presidential candidate and her fundraising advantage was one of the main reasons why Joseph Biden decided not to enter the race (Gaughan, 2016). The election system in which campaigns are privately financed without expenditure limits prevents many worthy but more ordinary candidates from participating in the election because the "threshold costs of entry" are unattainable to them. 


\section{Money Politics}

However, a more serious problem is the corrosive influence of money in politics. On the one hand, as candidates seek the maximum "return on investment ratio", voters with limited resources, lack of information and interest in politics are not their main target market (Ferguson, 1995). So there is less incentive for candidates to appeal to ordinal people. Once political parties and candidates realize that charities, foundations, and think tanks (Ferguson, 1995) are the main sources of funding, elections become a competition for funds rather than votes. On the other hand, the accumulation of wealth creates a demand for the perpetuation of privilege, making wealthy people realize that they need to use power to protect their interests, so wealth affords an excessive influence on government policy (Munger, 1996).

Even the most liberal or conservative presidential candidates will take a pro-business moderate attitude to become involved with powerful elites who are often members of a corporate community or wealthy upper class with money to contribute and connections to other states (Ehrenhalt, 1991). Ambitious Obama took a more moderate position when raising money in financial circles (Domhoff, 2014). Besides, most successful candidates remain silent on extreme social issues such as the death penalty or gun control in order to win the election (Domhoff, 2014).

\section{What Have Investors Got?}

The return on interest groups' investment is tremendous. From 2007 to 2012, the top 200 lobbying organizations spent $\$ 5.8$ billion on federal lobbying and campaign contributions and the return was $\$ 13$ trillion in federal business and $\$ 3.2$ trillion in federal support (Collins, 2015). Besides, they also get tax reductions, modify regulations, and affect international trade agreements, successfully transferring the wealth of the middle class (Collins, 2015). For example, the American Legislative Exchange Council (ALEC) have contributed over $\$ 370$ million to state elections and in turn, they have got money from energy, drug, loan companies, and private prison operators by lobbing against environmental controls, importing discounted drugs, charging interest, as well as advocating the detention of undocumented immigrants and the restriction of parole eligibility to raise prison occupancy rates (Collins, 2015).

\section{Manipulation in the Digital Age}

Democracy depends on the ability and the will of voters to make their political judgments based on facts, or at least on intermediary institutions which can provide sufficient information and guide decision making (Persily, 2017). Digital tools were thought to be able to expand citizen empowerment and engagement, However, unlike traditional media, new social media were created without the aim of promoting democratic values and fostering well-informed and civically minded electors, on the contrary, its anonymity, liberating, anti-establishment potential, and lack of accountability can be exploited by demagogues, bringing about challenges to American democracy (Persily, 2017).

In the 2016 presidential election, Cambridge Analytica purchased more than 87 million people's records from Facebook (Isaak \& Hanna, 2018), then did data analytics to find out the voters' personality traits and political leanings. They used a secret self-destructing email system that leaves no trace: the emails disappeared automatically two hours later, after having been read (Channel 4 News, 2018). Before the election, the company targeted their messages precisely to undecided voters in Wisconsin, Michigan, and Pennsylvania and at the same time, spread discreetly negative information about the opponent candidate on the Internet and social media (Channel 4 News, 2018). The transformation of data into a political messaging weapon helped Trump to narrowly win the election. Thus the development of information technology has made the U.S. elections more susceptible to being manipulated.

\section{Wrong Winner}

There is another problem that the Electoral College does not help the winner achieve their missions because it gives up the requirements of the capacity of presidents to govern successfully (Edwards, 2019). With the development of information technology and mass media, the chance for presidential candidates to be elected by influencing public opinion has been increasing. A successful presidential candidate does not have to be a traditional political elite, especially since Trump came to power, whose personal character and performance have challenged people's perception of an American president. According to the "Ranking of U.S. Presidents by 'Presidential Greatness Score' in 2018" published by the American Political Science Association, Donald Trump debuted on the list in last place (Statista, 2019).

To win the election, presidential candidates do not need to persuade voters that he or she is the most competent. They just need to prove that they are more capable than the others, or in other words, their opponents are worse. 
Generally, once an incompetent president is elected, he can only be replaced at the end of his term, since it is not easy to impeach him due to complex procedures and ambiguous standards.

\section{Solutions Proposed}

The Electoral College system not only failed to protect the interests of states with small populations and the interests of the majority but provided opportunities for special interest groups to have disproportionate power (Schumaker, 2005). Although some candidates such as Clinton have offered campaign finance reform proposals, their policies are unlikely to threaten the existing political foundations, nor go against the wishes of interest groups. They can only make limited adjustments or allow soft money to flood in colossal amounts (Ferguson, 1995). There are also other propositions such as eliminating the Electoral College as a whole and implementing direct election, applying the National Popular Vote Interstate Compact. But the practicability of those methods is debatable. It is quite intractable and complicated to find a perfect reform method to achieve the goal of democracy and balance the interests of different groups.

\section{Election Plus Selection}

A good electoral system not only needs to reflect the will of people to the largest extent but also needs a certain set of selection mechanisms to ensure its rationality.

Compared with the logic of election in Western countries that the ability of presidents is tested after being elected, the method of China's election is that only those who perform well or are at least competent in their former position can be selected for a higher-level position. To become a member of the seven top leaders in China, in most cases, a candidate needs to be the "number one leader" of a Chinese province for two terms. Given the size of the Chinese population, it means that the candidate must have governed at least one hundred million people before having the qualification to be nominated for the position (Munk Dialogues, 2021). China was also made up of many different states (zhuhou guo in Chinese) in the long history before becoming a united nation. The population is large and diverse, the resources per capita are relatively fewer than other countries, so it is a country challenging to govern. Keju system which was introduced thousands of years ago and today's public service exam system are all a kind of meritocracy, guaranteeing the governance ability of national leaders and the development of the country.

In the 13th century, an important design of the electoral system of the Republic of Florence was to review candidates' conditions in the pre-selection to exclude "unqualified" candidates (Finer, 2014). Nowadays prime ministers of Western countries such as the U.K. and Germany are also selected through a process of vetting, intra-party voting, and parliamentary election. The selection process for candidates is in fact a kind of qualification review. Since the leaders are selected from political elites, a filtering mechanism can be created to keep out those incompetent candidates.

\section{Conclusion}

The American constitutional system was designed initially that the president cannot be directly elected by citizens but chosen by the Electoral College provisionally formed who were political elites of each state, with the purpose to take all measures to restrain collusion between powers, prevent corruption and preserve the democracy at the same time. Despite the careful intention of the founding fathers, the electoral system has not developed as they had planned. The anachronistic Electoral College system fills the country with agitation for more than six months every four years, stimulating personal ambitions for power, allowing people's votes have different weights, putting the interests of ordinary people and the destiny of the country at risk (Beard, 1920). Limited adjustments to the electoral system are not enough. It is time to reform the electoral system to better achieve effective governance as well as defend democracy.

\section{References}

Ballotpedia. (n.d.). Ballot access for presidential candidates. Retrieved from https://ballotpedia.org/Ballot_access_for_presidential_candidates\#

Ballotpedia. (n.d.). Historical signature requirements for independent and minor party presidential candidates. Retrieved from https://ballotpedia.org/Historical_signature_requirements_for_independent_and_minor_party_presidential_ candidates

Bartels, L. M. (2016). Unequal democracy. Princeton University Press.

Beard, C. A. (1920). American government and politics. Macmillan.

Bennett, R. W. (2006). Taming the electoral college. Stanford University Press. 
Channel 4 News. (2018, March 20). Exposed: Undercover secrets of Trump's data firm. Retrieved from https://www.channel4.com/news/exposed-undercover-secrets-of-donald-trump-data-firm-cambridge-analyti $\mathrm{ca}$

Collins, M. (2015, March 28). Buying Government with Lobbying Money. Forbes. Retrieved from https://www.forbes.com/sites/mikecollins/2015/03/28/buying-government-with-lobbying-money-2/?sh=3f7 b17d56b93

Domhoff, G. W. (2014). Who Rules America? The Triumph of the Corporate Rich. McGraw-Hill Education.

Edwards, G. C. (2019). Why the Electoral College is Bad for America. Yale University Press.

Ehrenhalt, A. (1991). The United States of ambition: Politicians, power, and the pursuit of office. Times Books.

FairVote. (n.d.). Population vs. Electoral Votes. Retrieved from https://www.fairvote.org/population_vs_electoral_votes

Federal Election Commission. (n.d.). Public funding of presidential elections. Retrieved from https://www.fec.gov/introduction-campaign-finance/understanding-ways-support-federal-candidates/preside ntial-elections/public-funding-presidential-elections/

Ferguson, T. (1995). Golden rule: The investment theory of party competition and the logic of money-driven political systems. University of Chicago Press.

Finer, S. E. (2014). The History of Government: the intermediate ages. Oxford University Press.

Galen, R. (2018, April 17). How Republicans and Democrats prevent independent candidates from getting on the ballot. Think. Retrieved from https://www.nbcnews.com/think/opinion/how-republicans-democrats-prevent-independent-candidates-getti ng-ballot-ncna866466

Gallup. (n.d.). Party Affiliation. Retrieved from https://news.gallup.com/poll/15370/party-affiliation.aspx

Gaughan, A. J. (2016). Ramshackle Federalism: America's Archaic and Dysfunctional Presidential Election System. Fordham Law Review, 85(3), 1021-1044.

Gerber, A., Huber, G., Dowling, C., Doherty, D., \& Schwartzberg, N. (2009, September 3-6). Using battleground states as a natural experiment to test theories of voting [Conference presentation]. American Political Science Association, Toronto, Canada. Retrieved from https://papers.ssrn.com/Sol3/papers.cfm?abstract_id=1451200

Godek, P. E. (2018). Determining State Preferences for the Electoral College: 1788-2016. Cato Journal, 38(3), 631-654.

Golder, M. (2006). Presidential coattails and legislative fragmentation. American Journal of Political Science, 50(1), 34-48.

Goux, D. J., \& Hopkins, D. A. (2008). The empirical implications of electoral college reform. American Politics Research, 36(6), 857-879.

Gumbel, A. (2008). Election fraud and the myths of American democracy. Social Research, 75(4), 1109-1134.

Hamilton, A. (1788, March 14). Federalist No. 68: The Mode of Electing the President. New York Packet.

Hamilton, A., Madison, J., \& Jay, J. (2009). The federalist papers. Yale University Press.

Isaak, J., \& Hanna, M. J. (2018). User data privacy: Facebook, Cambridge Analytica, and privacy protection. Computer, 51(8), 56-59.

Kousser, J. M. (1974). The shaping of Southern politics: Suffrage restriction and the establishment of the one-party South, 1880-1910 (Vol. 102). Yale University Press.

Kuroda, T. (1994). The Origins of the Twelfth Amendment: The Electoral College in the Early Republic, 1787-1804. Greenwood Press.

Lijphart, A. (1999). Patterns of democracy: Government forms and performance in thirty-six countries. Yale University Press.

Lipset, S. M., \& Marks, G. (2000). It didn't happen here: Why socialism failed in the United States. W. W. Norton \& Company. 
Liptak, A. (2010, January 21). Justices, 5-4, Reject Corporate Spending Limit. The New York Times. Retrieved from http://archive.nytimes.com/www.nytimes.com/2010/01/22/us/politics/22scotus.html

LoBianco, T. (2015, September 1). Scott Walker: 12 states will elect next president. CNN. Retrieved from https://edition.cnn.com/2015/09/01/politics/scott-walker-12-states-to-win/index.html

Marlowe, K. (2020). The Electoral College is Bad for Democracy. [Undergraduate dissertation, University of Tennessee]. TRACE. Retrieved from https://trace.tennessee.edu/utk_chanhonoproj/2399

Moore, J. L., Preimesberger, J. P., \& Tarr, D. R. (2001). Congressional Quarterly's guide to US elections (Vol. 2). CQ Press.

Munger, M. C. (1996). Review: Golden Rule: The Investment Theory of Party Competition and the Logic of Money-Driven Political Systems. The Independent Review. Retrieved from https://www.independent.org/publications/tir/article.asp?id=487

Munk Dialogues. (2021, January 29). Munk Dialogues Zhang Weiwei: What Do The Chinese Think of Democracy [Video]. YouTube. Retrieved from https://www.youtube.com/watch?v=muqUPIIMUAU

Narayanswamy, A., Cameron, D., \& Gold, M. (2021, February 1). Election 2016. The Washington Post. Retrieved from https://www.washingtonpost.com/graphics/politics/2016-election/campaign-finance/

Nivola, P. S., \& Brady, D. W. (2007). Red and blue nation?: characteristics and causes of America's polarized politics (Vol. 1). Brookings Institution Press.

Parenti, M. (1995). Democracy for the few. St. Martin's Press.

Persily, N. (2017). The 2016 U.S. Election: Can Democracy Survive the Internet?. Journal of Democracy, 28(2), 63-76.

Polsby, N. W., Wildavsky, A. B., \& Hopkins, D. A. (2008). Presidential elections: Strategies and structures of American politics. Rowman \& Littlefield.

Ross, R. E. (2015). Federalism and the Electoral College: The Development of the General Ticket Method for Selecting Presidential Electors. The Journal of Federalism, 46(2), 147-169. Retrieved from https://academic.oup.com/publius/article/46/2/147/2494081?login=true

Schumaker, P. (2005). Why the Electoral College Is Bad for America. Perspectives on Politics, 3(2), 373-374.

Shepard, S. (2016, August 6). The 11 states that will determine the 2016 election. Politico. Retrieved from https://www.politico.com/story/2016/06/donald-trump-hillary-clinton-battleground-states-224025

Stanage, N. (2016, July 9). Will Trump or Clinton win? The 11 states deciding the race. The Hill. Retrieved from https://thehill.com/homenews/campaign/294716-will-trump-or-clinton-win-the-11-states-deciding-the-race

Statista. (2019, July 30). Ranking of U.S. Presidents by "Presidential Greatness Socre" 2018. Retrieved from https://www.statista.com/statistics/816048/presidential-greatness-survey-scores-in-the-us/

Willsher, K. (2007, June 10). Financing French democracy. The Telegraph. Retrieved from https://www.telegraph.co.uk/news/worldnews/1554132/Financing-French-democracy.html

\section{Copyrights}

Copyright for this article is retained by the author(s), with first publication rights granted to the journal.

This is an open-access article distributed under the terms and conditions of the Creative Commons Attribution license (http://creativecommons.org/licenses/by/4.0/). 